\title{
Social Media as Online Mentoring Tools for STEM Students With and Without Disabilities
}

\author{
Robert L. Todd \\ Georgia Institute of Technology \\ CATEA \\ $49010^{\text {th }}$ Street \\ Atlanta, GA 30318 \\ USA \\ robert.todd@coa.gatech.edu
}

\begin{abstract}
Considerable attention has been given to the need for educating a diverse workforce in science, technology, engineering, and mathematics (STEM). Public and regulatory institutions have stressed the importance of efforts to recruit and retain students chronically underrepresented in STEM fields. Individuals with disabilities are among the most marginalized of these groups and face significant barriers to accessing higher education STEM programs. This paper will discuss affordances for e-mentoring of students in STEM education, with a focus on universal design for online learning and inclusion of all students, especially those with functional limitations due to disability. Preliminary data from ongoing research will be reviewed and discussed.
\end{abstract}

Keywords: e-mentoring, STEM, disability, social media, virtual worlds.

\section{Introduction}

Considerable attention has been given to the need for educating a diverse workforce in science, technology, engineering, and mathematics (STEM). United States National Science Foundation reports (NSF 1996, 2000, 2004) stress the importance of efforts to recruit and retain students chronically underrepresented in STEM fields. Individuals with disabilities are among the most marginalized of these groups (Wolanin \& Steele, 2004) and face significant barriers to accessing higher education STEM programs (Burgstahler, 1994; NSF, 2000). This paper will discuss affordances for ementoring of students with disabilities (SwD) in STEM education as an important component in the solution to this lack of representation.

Students with disabilities and their teachers use a variety of social media and computer-mediated communication $(\mathrm{CMC})$ tools in mentoring relationships through electronic mentoring (e-mentoring) (Todd, 2012). As e-mentoring can occur asynchronously, it has benefits not found with face-to-face (FtF) programs. While traditional FtF mentoring is often conceived as a dyadic relationship in which a senior, experienced individual provides support and guidance for a less-experienced one (Gay, 1994), e-mentoring has contributed to an expansion of this concept to include 
lateral, hierarchical, group and asynchronous versus synchronous mentoring and to applications in expanded contexts (Ensher, Heun \& Blanchard, 2003).

A growing literature base describes e-mentoring programs and their usefulness in educational, business, human resources, and social environments (Gregg, Chang, \& Todd, 2012; O’Neill \& Harris, 2004; Single \& Single, 2005) and e-mentoring has demonstrated positive impacts on at-risk students' educational and personal goals (iMentor project, MentorNet 2012, Todd, 2012). Furthermore, e-mentoring has shown benefits through removal of geographic boundaries, including international collaborations, and positive effects through multiple cohorts of students of different educational levels and inclusion of professionals (McCarthy, 2012). E-mentoring also has demonstrated advantages for numerically small, isolated members of underrepresented groups in specific STEM fields, empowering communication, support, information exchange and other mentoring activities where otherwise impossible (Jefferson, Hannula, Campbell, et al., 2010).

\section{Computer-Based Social Media Mentoring}

Potentially, any form of computer-mediated communication, from relatively early formats such as listservs and email to the latest applications can provide means for ementoring. But as social media platforms and tools (as typified by user-generated content (Agichtein, et al., 2008)) become more powerful and ubiquitous, options for e-mentoring continue to expand. McCarthy (2012) reports on the successful use of Facebook as an e-mentoring tool among students and professionals, across international boundaries and among multivariate cohorts. Jefferson, Hannula, Campbell, et al., (2010) discuss the affordances of online blogging tools as a means of mentoring among diverse and underrepresented geoscientists. Voice over IP (VoIP) tools like Skype have seen growing use as e-mentoring tools, both in one-on-one and group mentoring situations, and with disability-related support such as mentoring of special education teachers (Smith \& Israel, 2010). In addition, dedicated mentoring platforms, both software and browser-based, have grown in number and breadth of application, such as SocialLearn, as reported by Liu, Macintyre \& Ferguson (2012). In many e-mentoring programs, combinations of tools, processes and applications are employed to provide custom e-mentoring experiences, and researchers provide students with disability-specific solutions to accessibility challenges (Todd, 2012).

\section{$3 \quad$ Virtual Worlds}

Among the newer CMC technologies, virtual worlds, or simulated 2-D and 3-D online environments (e.g. Second Life), have become an increasingly common software platform for education and training applications during the last decade (cf. Chou \& Hart, 2012; Cremorne, 2009; deNoyelles \& Kyeong-Ju Seo, 2012; Kingston, 2011; Taylor, 2002; Jones, 2007; Brown \& Bell, 2004; Gerald \& Antonacci, 2009) including e-mentoring (Todd, 2012; de Freitas, 2008). Virtual platforms can present their own challenges to full accessibility, but proper design and use of assistive 
technologies can make them usable and effective for SwDs (Todd, Baker \& Pater, 2012; Folmer, Yuan, Carr \& Sapre, 2009; Forman, Baker, Pater \& Smith, 2012; Mancuso, Chlup, \& McWhorter, 2010; Stendal, Molka-Danielsen, Munkvold \& Balandin, 2011).

One common finding about the educational uses of virtual worlds is that immersion, or "the subjective impression that one is participating in a comprehensive, realistic experience" (Dede, 2009) can enhance the learning experience. Researchers have also observed that virtual worlds offer possibilities for experiential learning through specific mentoring activities; an approach that encourages students to engage in problem solving activities within a flexible environment that facilitates collaborative and constructivist learning (Cremorne, 2009). Educators have also been drawn to the potential that virtual worlds offer for distance mentoring through social interaction and learner engagement (Chou \& Hart, 2012). In these applications, the presence of avatars can enhance "engagement and learning beyond computer-mediated communication without such agents" (Jarmon, 2008). Researchers have also noted the capacity of virtual worlds to facilitate experiential learning (Jarmon, Traphagan, Mayrath \& Trivedi, 2009) via simulations, role-playing, and group work that can be used within mentoring activities (Duncan, Miller \& Jiang, 2012; Inman et al., 2010).

\section{Mobile Devices}

Like many CMC solutions, virtual worlds are still most easily accessed from traditional personal computers (PCs), but there are opportunities to supplement PC based e-mentoring with mobile devices. Within the CMC rubric, modern students are increasingly turning to mobile computing platforms to stay connected when away from a PC, and the most commonly used devices are smartphones (Herrington, 2009). As a CMC platform, the smartphone is rapidly maturing. According to a yearly survey of college students, 99\% own a cell phone, 69\% of which are smartphones (Hanley, 2012). Hanley also reports that $99 \%$ of students use short messaging service (SMS), also known as "texting," many of whom text even while in class. Research suggests that SMS classroom communication can be educationally effective when properly implemented (Markett, Sanchez, Weber, Tangney, 2008), and instructors are taking advantage of texting to implement anonymous response systems, polling, and just-intime communication techniques that have been used in mentoring (McClean, Hagan, \& Morgan, 2010). While smartphone accessibility is far from perfect, studies indicate a growing trend for accessible input and output in these devices, increasing their use by SwDs (Lippincott, Morris \& Mueller, 2011).

Smartphones also enable students to stay connected to social media on the go, including aforementioned tools such as Facebook. Patten, Sanchez and Tangney (2006) have identified several other common uses of smartphones by students, including video chatting and Tweeting. Research indicates that a majority of students use their smartphones for social stimulation, to remain continually available, to leave memos and reminders, and for time-keeping (Tindell \& Bohlander (2012). These tools all have potential benefits for mentoring (Todd, 2012; Khalil, 2008). 


\section{$5 \quad$ Preliminary Results from BreakThru Research}

Funded by the National Science Foundation Research in Disability Education division (award \# 1027655), the Georgia STEM Accessibility Alliance provides online mentoring to secondary and post-secondary students with disabilities in STEM education through its BreakThru project. BreakThru studies the use and effectiveness of online mentoring in high schools, two-year college and university settings and on students with a wide range of disabilities, including learning, mobility, dexterity, health, sensory and cognitive concerns. Students are paired with mentors who are STEM instructors, graduate students, or professionals employed in the STEM workforce. Mentors provide guidance, support, information and networking assistance to enrolled students, with all contact effected through social media methods, including a 3-D virtual world island, e-mail, Skype (audio-only and video with audio), SMS (texting via smartphone), and telephone voice communication. BreakThru has created virtual world islands through the medium of Second Life, providing accessibility modifications and features to include all participants. Students and mentors in the program are allowed to freely choose their preferred methods of communication from the aforementioned tools. In addition, some student/mentor pairs include limited face-to-face contact, where appropriate.

The following project data is formative and preliminary, excerpted from Fall 2012 BreakThru results, but may help to shed light on the ways in which students, teachers and professionals can incorporate social and online media into mentoring activities. More complete interpretive and summative data from BreakThru will be published in future.

Thirty mentees completed a survey in Fall 2012 that was designed to gauge their satisfaction with mentoring. The following constructs were assessed on the mentee survey:

1. Personal Responsibility: degree to which mentor enhances interpersonal development among mentees

2. Satisfaction: sense of fulfillment in the mentoring relationship

3. Communication-quantity: satisfaction with frequency and duration of communication (extent)

4. Communication-quality: satisfaction with the quality of communication

5. Support Seeking: degree of support provided (academic and personal)

Additionally, the mentee survey explores the types of communication mediums being utilized and the level of satisfaction with each medium.

\subsection{Results and Discussion}

Table 1 summarizes mentees' average responses to the constructs listed above. It is evident that all constructs were rated above the optimal average of 4 on a 5-point likert scale where 1 signifies strongly disagree and 5 signifies strongly agree. The results show that participants enjoyed and saw the benefits of the mentor/mentee 
program, especially in the communication realm. For example, all 30 of the mentees indicated that they always felt respected and supported during sessions with their mentors.

Table 1.

\begin{tabular}{lcccccc}
\hline \multicolumn{1}{c}{ Constructs } & Mean & $\begin{array}{c}\text { Strongly } \\
\text { Disagree } \\
(\mathbf{1})\end{array}$ & $\begin{array}{c}\text { Disagree } \\
\mathbf{( 2 )}\end{array}$ & $\begin{array}{c}\text { Neither } \\
\mathbf{( 3 )}\end{array}$ & $\begin{array}{c}\text { Agree } \\
\mathbf{( 4 )}\end{array}$ & $\begin{array}{c}\text { Strongly } \\
\text { Agree (5) }\end{array}$ \\
\hline $\begin{array}{l}\text { Personal } \\
\text { Responsibility }\end{array}$ & 4.34 & $0 \%$ & $1 \%$ & $10 \%$ & $44 \%$ & $46 \%$ \\
\hline Satisfaction & 4.53 & $0 \%$ & $0 \%$ & $7 \%$ & $33 \%$ & $60 \%$ \\
\hline $\begin{array}{l}\text { Communica- } \\
\text { tion-quantity }\end{array}$ & 4.40 & $0 \%$ & $0 \%$ & $12 \%$ & $36 \%$ & $52 \%$ \\
\hline $\begin{array}{l}\text { Communication- } \\
\text { quality }\end{array}$ & 4.68 & $0 \%$ & $0 \%$ & $3 \%$ & $25 \%$ & $71 \%$ \\
\hline Support Seeking & 4.41 & $0 \%$ & $0 \%$ & $9 \%$ & $42 \%$ & $49 \%$ \\
\hline
\end{tabular}

The same students responded to measures of engagement in the mentoring process via Second Life and other BreakThru social networking tools, such as Facebook, Twitter, email and Skype). Results indicated generally positive engagement, but suggested that Second Life may require further training or experience to be used most effectively. Students were, in general, less experienced and confident in use of the virtual world platform as opposed to more familiar affordances, and expressed some difficulties with technical issues, such as audio input and output in Second Life.

Table 2.

\begin{tabular}{|c|c|c|c|c|c|c|c|}
\hline Engagement & $\mathbf{n}$ & Mean & $\begin{array}{l}\text { Strongly } \\
\text { Disagree } \\
\text { (1) }\end{array}$ & $\begin{array}{c}\text { Disagree } \\
\text { (2) }\end{array}$ & $\begin{array}{c}\text { Neither/ } \\
\text { Neutral } \\
\text { (3) }\end{array}$ & $\begin{array}{c}\text { Agree } \\
\text { (4) }\end{array}$ & $\begin{array}{l}\text { Strong- } \\
\text { ly } \\
\text { Agree } \\
(5) \\
\end{array}$ \\
\hline $\begin{array}{l}\text { a. Using Second } \\
\text { Life for mentoring } \\
\text { was a positive } \\
\text { experience for me. }\end{array}$ & 30 & 3.37 & $10 \%$ & $10 \%$ & $33 \%$ & $27 \%$ & $20 \%$ \\
\hline $\begin{array}{l}\text { b. I feel } \\
\text { comfortable using } \\
\text { Second Life for } \\
\text { my mentoring. }\end{array}$ & 29 & 3.31 & $10 \%$ & $10 \%$ & $31 \%$ & $34 \%$ & $14 \%$ \\
\hline $\begin{array}{l}\text { c. Using social } \\
\text { networks (such as } \\
\text { Facebook, Twitter, } \\
\text { email, Skype) } \\
\text { helped me build a } \\
\text { relationship with } \\
\text { my mentee. }\end{array}$ & 30 & 4.27 & $7 \%$ & $0 \%$ & $10 \%$ & $27 \%$ & $57 \%$ \\
\hline
\end{tabular}


Table 2. (continued)

\begin{tabular}{llllllll}
\hline $\begin{array}{l}\mathrm{d} \text {. My } \\
\text { background/ } \\
\text { experiences allow }\end{array}$ & 29 & 4.31 & $3 \%$ & $0 \%$ & $0 \%$ & $55 \%$ & $41 \%$ \\
$\begin{array}{l}\text { me to relate to my } \\
\text { mentee. }\end{array}$ & & & & & & \\
\hline
\end{tabular}

Frequency of use of communication media and student self-report indicate that they tended to use the tools most familiar to them and most readily "at-hand," including tools available through portable mobile devices such as smartphones.

Table 3.

\begin{tabular}{cccc}
\hline $\begin{array}{c}\text { Check all the ways you communicate } \\
\text { with your mentor } \\
\text { (Please check all that apply.) }\end{array}$ & $\mathbf{n}$ & $\%$ & Rank \\
\hline Second Life & 14 & $47 \%$ & 4 \\
\hline Email & 29 & $97 \%$ & 1 (highest) \\
\hline Facebook & 10 & $33 \%$ & 5 \\
\hline Twitter & 0 & $0 \%$ & 8 (lowest) \\
\hline Skype & 9 & $30 \%$ & 6 \\
\hline Texting & 18 & $60 \%$ & 3 \\
\hline Telephone & 23 & $77 \%$ & 2 \\
\hline In person & 7 & $23 \%$ & 7 \\
\hline Other & 0 & $0 \%$ & 8 (lowest) \\
\hline
\end{tabular}

Results with students and mentors indicated a need for training on multiple levels, but especially in the use of the virtual world platform of Second Life, largely unfamiliar to all respondents. A 1.5 hour virtual training session was conducted with project participants in Fall 2012, and results from one cadre of 21 students and 12 mentor trainees are summarized below. Trainees were instructed in basic movement of avatars, communicating with others, and advanced features, such as accessing web media through Second Life, group communications, manipulating in-world objects and travelling to alternate destinations.

On average, participants rated all of the agenda items above the critical limit of 3.5 or higher. Overall, the participants rated the agenda topics as a 3.75 for informative, a 3.85 for useful, and a 3.74 for engaging on a 4-point likert scale where 1 signifies "not at all" and 4 signifies "very much." Given that the primary goal of Second Life is to interact and learn with other participants, reinforcing the importance of communicating with other avatars may warrant further training. 
Table 4.

\begin{tabular}{|l|c|c|}
\hline & Mean $^{\mathbf{1}}$ & Rank \\
\hline Basic Movement (forward, backwards, turning, jumping) & 3.91 & 1 (highest) \\
\hline Communicating with other users & 3.68 & 3 (lowest) \\
\hline Advanced features & 3.70 & 2 \\
\hline Overall average & $\mathbf{3 . 7 6}$ & \\
\hline
\end{tabular}

In responses to the open-ended questions, participants indicated that they need additional technical assistance in creating and navigating their avatars, and in reconciling audio problems encountered during the training session(s).

Table 5.

\begin{tabular}{|c|c|c|c|c|c|c|c|}
\hline Modules & & $\mathrm{N}$ & Mean & $\begin{array}{l}1 \text { (not at } \\
\text { all) }\end{array}$ & 2 & 3 & $\begin{array}{l}4 \text { (to a } \\
\text { great } \\
\text { extent) }\end{array}$ \\
\hline \multirow{3}{*}{$\begin{array}{l}\text { Basic Move- } \\
\text { ment (forward, } \\
\text { backwards, } \\
\text { turning, jump- } \\
\text { ing) }\end{array}$} & Informative & 20 & 3.95 & $0 \%$ & $0 \%$ & $5 \%$ & $95 \%$ \\
\hline & Useful & 19 & 3.89 & $0 \%$ & $0 \%$ & $11 \%$ & $89 \%$ \\
\hline & Engaging & 18 & 3.89 & $0 \%$ & $0 \%$ & $11 \%$ & $89 \%$ \\
\hline \multirow{3}{*}{$\begin{array}{l}\text { Communicating } \\
\text { with other users }\end{array}$} & Informative & 19 & 3.74 & $0 \%$ & $5 \%$ & $16 \%$ & $79 \%$ \\
\hline & Useful & 19 & 3.74 & $0 \%$ & $5 \%$ & $16 \%$ & $79 \%$ \\
\hline & Engaging & 19 & 3.58 & $0 \%$ & $11 \%$ & $21 \%$ & $68 \%$ \\
\hline \multirow{3}{*}{$\begin{array}{l}\text { Advanced } \\
\text { features }\end{array}$} & Informative & 20 & 3.55 & $5 \%$ & $5 \%$ & $20 \%$ & $70 \%$ \\
\hline & Useful & 18 & 3.78 & $0 \%$ & $0 \%$ & $22 \%$ & $78 \%$ \\
\hline & Engaging & 17 & 3.76 & $0 \%$ & $6 \%$ & $12 \%$ & $82 \%$ \\
\hline
\end{tabular}

In terms of comfort using the Second Life platform for e-mentoring, the training indicates that both students and mentors can quickly achieve a reasonable level of satisfaction, but further training and experience may be necessary to achieve a target mean of 3.5 or higher, which would indicate "great extant" of comfort.

Table 6.

\begin{tabular}{|l|c|c|c|c|c|c|}
\hline $\begin{array}{l}\text { Based on today's training, } \\
\text { I... }\end{array}$ & $\mathbf{n}$ & Mean & 1 (not at all) & $\mathbf{2}$ & $\mathbf{3}$ & $\begin{array}{c}\text { 4 (to a great } \\
\text { extent) }\end{array}$ \\
\hline $\begin{array}{l}\text { Am more comfortable using } \\
\text { Second Life }\end{array}$ & 21 & 3.48 & $0 \%$ & $10 \%$ & $33 \%$ & $57 \%$ \\
\hline $\begin{array}{l}\text { Am better able to use } \\
\text { Second Life to support } \\
\text { students. }\end{array}$ & 12 & 3.50 & $0 \%$ & $8 \%$ & $33 \%$ & $58 \%$ \\
\hline $\begin{array}{l}\text { Am comfortable with the } \\
\text { amount of support the } \\
\text { trainers provided. }\end{array}$ & 21 & 3.62 & $0 \%$ & $5 \%$ & $29 \%$ & $67 \%$ \\
\hline
\end{tabular}




\section{Conclusion}

CMC solutions, including virtual worlds and smartphone technologies, open new possibilities for e-mentoring SwDs. Virtual worlds include technology, accessibility and learning challenges for many students, but can provide a rich mentoring experience with increased sense of immersion, with proper training. Mobile computing platforms such as smartphones can supplement more traditional PC-based ementoring, and in some cases can provide equivalent affordances to typical CMCs, such as e-mail, Skype, Facebook, browser-based applications, and other social media tools. They also have the advantage of convenience and nearly ubiquitous access for many students.

Overall, the preliminary BreakThru results suggest that mentoring activities gravitate to media that are familiar and comfortable to participants. The top 3 media for communicating with mentors were: Email, Telephone, and Texting. It is also possible that because of technical complications (i.e. audio problems), mentors and mentees have made less use of the virtual world option than may otherwise have been the case.

\section{References}

1. Agichtein, E., Castillo, C., Donato, D., Gionis, A., Mishne, G.: Finding High Quality Content in Social Media, with an Application to Community-Based Question Answering. In: Proc. ACM Web Search and Data Mining (WSDM), Stanford, CA, USA (2008)

2. Brown, B., Bell, M.: CSCW at play: 'There' as a collaborative virtual environment. In: Proceedings of the 2004 ACM Conference on Computer Supported Cooperative Work, CSCW 2004, pp. 350-359. Association for Computing Machinery, New York (2004)

3. Burgstahler, S.: Increasing the representation of people with disabilities in science, engineering and mathematics. Journal of Information Technology for Development 4(9), 1-8 (1994)

4. Chou, C.C., Hart, R.K.: The Pedagogical Considerations in the Design of Virtual Worlds for Organization Learning. In: Yang, H., Yuen, S. (eds.) Handbook of Research on Practices and Outcomes in Virtual Worlds and Environments, pp. 551-569 (2012)

5. Cremorne, L.: Interview-Denise Wood, University of South Australia. Metaverse Journal-Virtual World News (November 2, 2009)

6. Dede, C.: Immersive Interfaces for Engagement and Learning. Science 323(5910), 66-69 (2009)

7. de Freitas, S.: Serious virtual worlds: a scoping study. JISC, Bristol (2008), http://www.jisc.ac.uk/media/documents/publications / seriousvirtualworldsv1.pdf (retrieved February 4, 2009)

8. de Noyelles, A., Kyeong-Ju Seo, K.: Inspiring equal contribution and opportunity in a 3D multi-user virtual environment: Bringing together men gamers and women non-gamers in Second Life. Computers \& Education 58(1), 21-29 (2012)

9. Duncan, I., Miller, A., Jiang, S.: A taxonomy of virtual worlds usage in education. British Journal of Education Technology (2012) 
10. Folmer, E., Yuan, B., Carr, D., Sapre, M.: TextSL: a command-based virtual world interface for the visually impaired. In: Proceedings of the 11th International ACM SIGACCESS Conference on Computers and Accessibility, Assets 2009, pp. 59-66. Association for Computing Machinery, New York (2009)

11. Forman, A.E., Baker, P.M.A., Pater, J., Smith, K.: The Not So Level Playing Field: Disability Identity and Gender Representation in Second Life. In: Livermore, C. (ed.) Gender and Social Computing: Interactions, Differences, and Relationships. IGI Global, Hershey (2012)

12. Gerald, S., Antonacci, D.M.: Virtual World Learning Spaces: Developing a Second Life Operating Room Simulation. Educause Quarterly 32(1) (2009),

http: / / www . educause. edu / EDUCAUSE+Quarterly/EDUCAUSEQuarterly MagazineVolum/VirtualWorldLearningSpacesDeve/163851 (retrieved June 21, 2011)

13. Gregg, N., Chang, Y., Todd, R.: Social Media, Avatars, and Virtual Worlds: Re-Imagine an Inclusive Learning Environment for Adolescents and Adults with Literacy Barriers. Procedia Computer Science Journal 10 (2012) (in press)

14. Hanley, M.: Ball State University Student Cell Phone Usage February 2009 - February 2012. International Journal of Mobile Marketing (2012) (in press)

15. Herrington, A.: Using a smartphone to create digital teaching episodes as resources in adult education. In: Herrington, J., Herrington, A., Mantei, J., Onley, I., Ferry, B. (eds.) New Technologies, New Pedagogies: Mobile Learning in Higher Education, pp. 28-35. University of Wollongong, Wollongong (2009), http: / / ro . uow. edu . au /

16. iMentor project: iMentor Program Impact (2009),

http://www. imentor.org/what/impact.php\#eval_out (accessed September 2012)

17. Inman, C., et al.: Use of Second Life in K-12 and Higher Education: A Review of Research. Journal of Interactive Online Learning 9(1) (2010)

18. Jarmon, L.: Pedagogy and Learning in the Virtual World of Second Life. In: Rogers, P., Berg, G., Boettcher, J., Howard, C., Justice, L. (eds.) Encyclopedia of Distance and Online Learning (2008)

19. Jarmon, L., Traphagan, T., Mayrath, M., Trivedi, A.: Virtual world teaching, experiential learning, and assessment: An interdisciplinary communication course in Second Life. Computers \& Education 53(1), 169-182 (2009)

20. Jefferson, A.J., Hannula, K.A., Campbell, P.B., et al.: The internet as a resource and support network for diverse geoscientists. GSA Today 20(9), 59-61 (2010)

21. Jones, D.E.: I, Avatar: Constructions of Self and Place in Second Life and the Technological Imagination. Gnovis, the Peer-Reviewed Journal of Communication, Culture and Technology 6 (2007)

22. Kingston, L.: Virtual world, real education: A descriptive study of instructional design in Second Life. Capella University (2011)

23. Lippincott, B., Morris, J., Mueller, J.: Keeping in Touch: Smartphone Touchscreens and Customers with Disabilities. Rehabilitation Engineering Research Center for Wireless Technologies (Wireless RERC), Atlanta, Georgia (2011)

24. Liu, H., Macintyre, R., Ferguson, R.: Exploring qualitative analytics for e-mentoring relationships building in an online social learning environment, Vancouver, Canada. Paper Presented at LAK12: 2nd International Conference on Learning Analytics and Knowledge (April 2012), http: / / oro.open.ac.uk/33632 (retrieved June 12, 2012)

25. Mancuso, D.S., Chlup, D.T., McWhorter, R.R.: A study of adult learning in a virtual environment. Advances in Developing Human Resources 12(6), 681-699 (2010) 
26. Markett, C., Sanchez, I., Weber, S., Tangney, B.: Using short message service to encourage interactivity in the classroom. Computers \& Education 46(3), 280-293 (2006)

27. McCarthy, J.: International design collaboration and mentoring for tertiary students through Facebook. Australasian Journal of Educational Technology 28(5), 755-775 (2012)

28. McClean, S., Hagan, P., Morgan, J.: Text Messaging for Student Communication and Voting. Bioscience Education (2010),

http: / / www.bioscience.heacademy.ac.uk/journal/vol16/

beej-16-4 . aspx (accessed May 2012)

29. Khalil, M.A.: Promoting Success: Mentoring Students with Disabilities Using New Technologies in Higher Education. Library Hi Tech News 25(1), 8-12 (2008)

30. National Science Foundation (NSF): Shaping the future: New expectations for undergraduate education in science, mathematics, engineering, and technology (NSF 96-139) (1996)

31. National Science Foundation (NSF): Land of plenty: Diversity as America's competitive edge in science, engineering and technology. Author., Arlington (2000)

32. National Science Foundation.: Women, minorities, and persons with disabilities in science and engineering (NSF 04-317) (2004)

33. O'Neill, D.K., Harris, J.B.: Bridging the perspectives and developmental needs of all participants in curriculum-based telementoring programs. Journal of Research on Technology in Education 37(2), 111-128 (2004)

34. Patten, B., Sanchez, I.A., Tangney, B.: Designing collaborative, constructionist and contextual applications for handheld devices. Computers \& Education 46(3), 294-308 (2006)

35. Single, P.B., Single, R.: E-mentoring for social equity: Review of research to inform program development. Mentoring and Tutoring 13, 301-320 (2005)

36. Smith, S.J., Israel, M.: E-mentoring: Enhancing special education teacher induction. Journal of Special Education Leadership 23(1), 30-40 (2010)

37. Stendal, K., Molka-Danielsen, J., Munkvold, B.E., Balandin, S.: Initial Experience with Virtual Worlds for People with Lifelong Disability: Preliminary Findings. Nokobit, pp. 105-118. The University of Nordland (2011)

38. Taylor, T.L.: Living Digitally: Embodiment in Virtual Worlds. In: Schroeder, R. (ed.) The Social Life of Avatars: Presence and Interaction in Shared Virtual Environments. Springer, London (2002)

39. Tindell, D., Bohlander, R.: The use and abuse of cell phones and text messaging in the classroom: a survey of college students. College Teaching 60(1), 1-9 (2012)

40. Todd, R.: BreakThru Research Data Autumn 2012. Georgia Institute of Technology, Center for Assistive Technology \& Environmental Access (2012), http: / /www.georgiabreakthru . org (accessed December 2012)

41. Todd, R., Baker, P., Pater, J.: (In)Accessible Learning in Virtual Worlds. Virtual Worlds in Online and Distance Education. Athabasca University Press, Edmonton (2012)

42. Wolanin, T.R., Steele, P.E.: Higher education opportunities for students with disabilities. The Institute for Higher Education Policy, Washington, DC (2004) 